Portland State University

PDXScholar

$1-1-2007$

\title{
The Meaning of Falling Water: Celilo Falls and the Dalles in Historical Literature
}

William L. Lang

Portland State University, langw@pdx.edu

Follow this and additional works at: https://pdxscholar.library.pdx.edu/hist_fac

Part of the United States History Commons

Let us know how access to this document benefits you.

Citation Details

Lang, W. L. (2007). The meaning of falling water: Celilo Falls and the Dalles in historical literature. Oregon Historical Quarterly, 108(4), 566-585.

This Article is brought to you for free and open access. It has been accepted for inclusion in History Faculty Publications and Presentations by an authorized administrator of PDXScholar. Please contact us if we can make this document more accessible: pdxscholar@pdx.edu. 


\section{The Meaning of Falling Water}

\section{Celilo Falls and The Dalles in Historical Literature}

NO PLACE STANDS STILL. IN MEANING. Human experiences, perceptions, and purposes attached to geographical locations change over time and alter the ways places relate to the lives of individuals and communities. Our connection to place is constantly changing as its physical composition changes, its cultural references alter, and individual connections revise. Understanding place, as one prominent historical geographer has argued, is not a problem but a riddle. Place is a riddle because it accommodates human experience and expression, while it exists as a physical location. We can best wrestle with the riddle by paying attention to our conversation about place, especially why we identify it as we do and how we have thought about it over time. Physical structure and location dominate our references - a mountain locale, desert expanse, or specific urban district - and so it is with Celilo Falls and The Dalles on the Columbia River. Much of the conversation has been about a place of falling water, about a locale where a great river is constricted and tumult rules. Not surprisingly, what meaning is attached to that dramatic place depends on who sees the falling water, when they view it, and what difference it makes to their lives. There is no singular viewpoint on places of meaning. ${ }^{1}$

In 1825, those distant from the West coast of North America knew about the Columbia River, but not a great deal. Mariners had spread the word about the river's rough sea entrance, and the few published explorers' reports included an outline of the river's course and the remarkable basalt gorge that cut through the Cascade Mountains about 120 miles upriver from the mouth. One extended place along that stretch of river in 
the 3,000-foot-deep gorge drew special attention - Celilo Falls and The Dalles, a series of cataracts that squeezed the river's great flow to a narrowed width and dropped it precipitously, creating one of the most productive fishing sites in North America. Celilo Falls and The Dalles - or the "Great Falls of the Columbia," as explorers Meriwether Lewis and William Clark labeled it on their maps - were far more complex places than even the most knowledgeable nonresident could have understood in 1825. The image of the place, though, was unmistakable in the published literature. Writers highlighted its physical drama as a spectacular landscape and its social and economic function as an enormously productive fishery and a dynamic trading place.

On the whole, the earliest published descriptions of the Celilo Falls-The Dalles landscape offered an accurate, if incomplete, description of the place and hinted at its important role on the Columbia River. The descriptions came from visitors, people who passed by and perceived the place in transit, as a living tableau. Cultural geographer Yi-Fu Tuan characterizes all visitors' descriptions of place as "essentially aesthetic," the result of looking at the landscape and noting novelty, narrowly perceived use, or recognizable beauty. Those descriptions are

Clark's sketch map of the Long and Short Narrows, dated October 22-28, 1805, shows the river from Wishram Village, at the top, to present-day Crates Point near The Dalles, at the bottom.

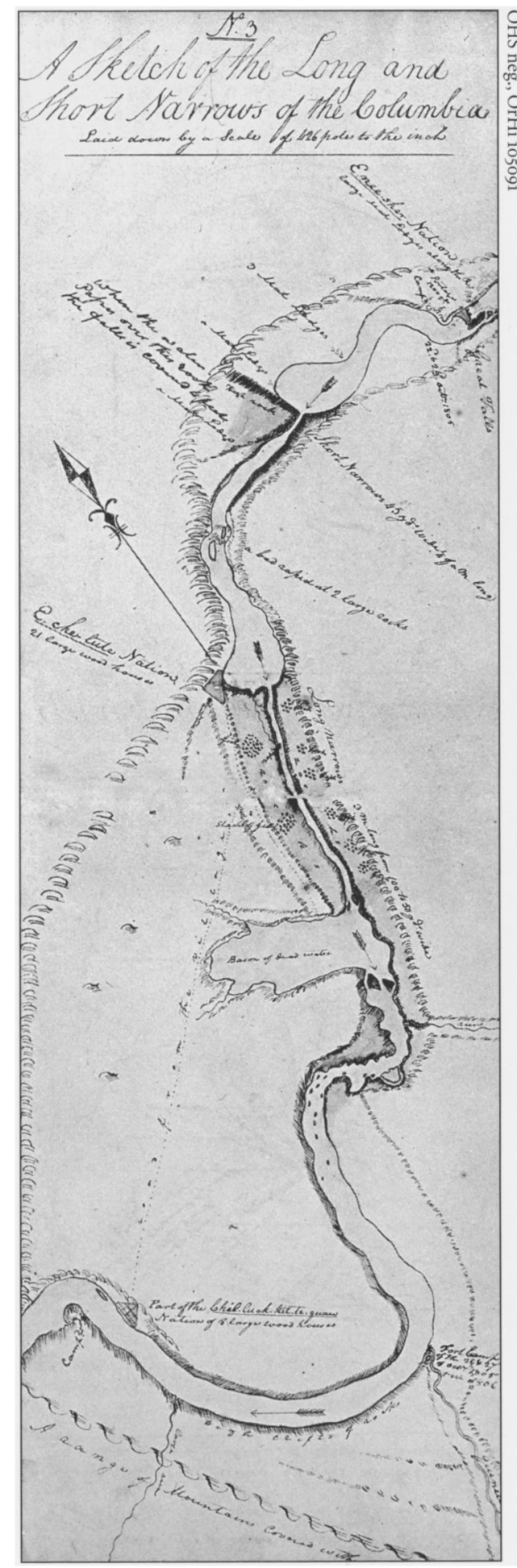


especially simple when compared to descriptions that could be offered by residents. The first published descriptions of Celilo Falls-The Dalles document Tuan's point. They focus on the unusual and the instrumental, on what a powerful place it seemed to be and how it might bring great benefit to anyone who could possess it. In 1807, Patrick Gass, a sergeant in the Lewis \& Clark Expedition, published the first account of the expedition's travel on the Columbia River, including the first written description of Celilo Falls and The Dalles. Gass's journal, which his publisher in Pittsburgh polished for better reading, met an avid audience, selling out quickly and justifying succeeding editions in 1808, 1810, 1811, and 1812. A French edition appeared in 1810, and at least one westering fur trapper, Andrew Henry, took a copy of Gass's journal with him into the Rockies that year. The Gass description of Celilo Falls invoked experiential understanding: "About the great pitch [Celilo Falls] the appearance of the place is terrifying, with vast rocks, and the river below the pitch, foaming through different channels." It was a place perfect for fishing, Gass tells his readers, because salmon can easily

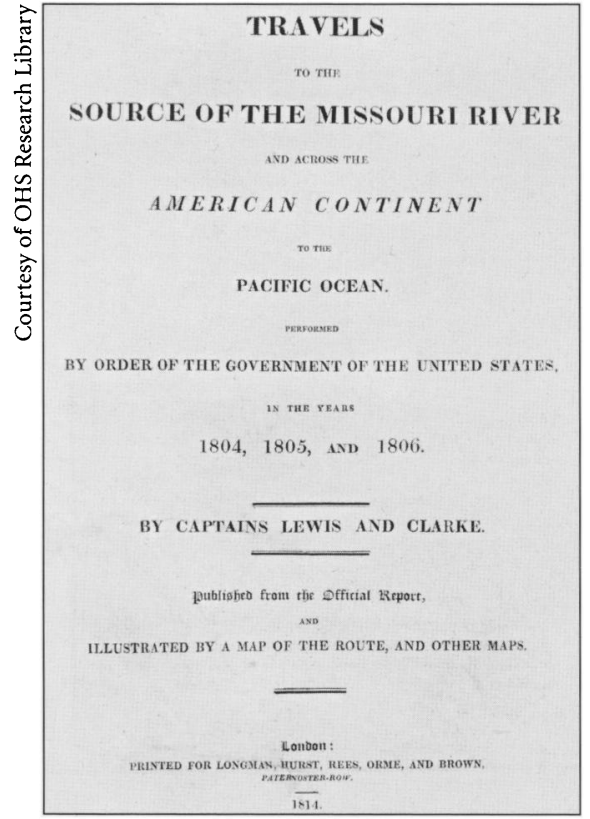

Both Nicholas Biddle's History of the Expedition under the Command of Lewis and Clark and this nearly verbatim version, Travels to the Source of the Missouri River, were published in 1814. ascend in the spring until they are forced to concentrate at the falls. The falls were "terrifying," but it was also a place that produced wealth. ${ }^{2}$

By 1814, when Nicholas Biddle edited and published a two-volume edition of the Lewis and Clark Expedition journals, maps outlining the course of the Columbia River, including the gorge and the falls, had also been published, including the large map that William Clark had completed in 1810 . The Biddle edition included the captains' extensive commentary on the activities of the Indian people they encountered on the river in the fall of 1805 and in the spring of 1806. The Biddle rendering of the explorers' experience at the falls in 1805 emphasized the travails of passage and the challenge of negotiating a river that "was divided into several narrow channels, by rocks and islands," requiring that they examine its structure and plan a safe descent. The captains commented on "the pilfering of the natives, which we apprehend much more than we do their hostilities," but they did 
not hesitate "to follow the route adopted by the Indians themselves" and admitted that the work of portaging around the worst of the obstructions "would have been very inconvenient, if the Indians had not assisted us in carrying some of the heavy articles on their horses." ${ }^{3}$ Lewis and Clark also looked at the "Great Falls of the Columbia" instrumentally, as part of a potential commercial pathway across the continent. Indian fishing interested them, but more important to them was the implication of ownership and control. Readers of Biddle's version of the first American land exploration of the Columbia could not have missed the characterization of the falls as a problematic place, a potential obstacle to economic use.

Exploration did not lead to settlement in the region, but it did help stimulate capitalist investment, the leading edge of Euro-American incursion into the Columbia Basin. John Jacob Astor's Pacific Fur Company arrived in 1811, as did David Thompson of the Northwest Company, but it was the British-chartered Hudson's Bay Company (HBC) in the 1820 s that brought a powerful transnational trading network to the Columbia. HBC traders and other travelers quickly recognized the falls on the mid-Columbia as a critical landscape in their operations, but it would be years before their accounts found their way to publication. Nonetheless, by the 1840 , when American emigrants began streaming overland to the Oregon Country, several published travelers' accounts and memoirs had added new descriptions of Celilo and The Dalles, usually commenting more on how effectively Indian groups possessed the place than on the danger inherent in descending the river. Lewis and Clark had complained about what they believed was Indian obstinacy at the falls, but their comments documented only solitary incidents in a fast-paced transit that read more as an adventure story than an economic survey. Travelers and fur traders saw the falls in much different context, one that valued economic efficiency in travel and commerce. For them, Indian guardians of the place stood as gatekeepers, impediments to economic intercourse.

Washington Irving's creative and widely read description of Astor's enterprise, Astoria, introduced readers to a "slippery people" at Celilo and The Dalles, who were "shrewder and more intelligent" than the Indians the 1811 overland travelers had encountered in their difficult journey from the Missouri to Astoria. In the Irving recounting, the Wishrams at Celilo used ruses and clever dealings to extract surreptitious tolls from travelers. The Dalles and Celilo emerged less as a geographical place than a place of intrigue and social conflict, a choke-point that could be passed only by intelligent diplomacy. John K. Townsend, a naturalist who traveled with a later furtrading enterprise, published an account of his experiences in 1839, three years after Irving's Astoria. Townsend saw the falls primarily as a threatening 
environment, which he portrayed as a tempestuous place where the river narrowed to fifteen-foot wide passages, the water roiling and foaming "like an enormous cauldron." His portrayal of the Indian guides who facilitated passage was disdainful and prejudiced, as if their presence on the river was illegitimate. A decade later, in Adventures of the First Settlers on the Oregon or Columbia River, Alexander Ross recounted his trip up the river in 1811 as a Pacific Fur Company employee. Describing the falls landscape as a "bare, rugged, and rocky" place that was "swarming with Indians, all as anxious to get to us as we were to avoid them," Ross characterized The Dalles as "the great emporium or mart of the Columbia." Almost grudgingly, he acknowledged Indian control of the landscape. No visitor, Ross implied, could miss the central importance of the place to Indian residents and the thousands of indigenous people who came there "for trade and traffic" and for socializing at a "great rendezvous during the summer."

Popular travelers' accounts of their experiences on the Columbia River always mentioned Celilo Falls and The Dalles. Among the first published was Samuel Parker's Journal of an exploring tour beyond the Rocky Mountains. The first of a string of Protestant missionaries who headed west to minister to Indians, Parker traveled with fur traders to the Rockies and then trekked overland to the Columbia in 1835 . His account, which gained popularity through the religious press, portrayed the region and its people in appealing ways, often quite at odds with the fur traders' perceptions. He characterized Indians above Celilo "as living in harmony, without any feuds or jealousies. It speaks much in favour of their kind and peaceable dispositions." When he encountered Indians who fished at Celilo, Parker thought them untidy and careless about their appearance, but he took note of their industry and the centrality of salmon fishing to their lives. What struck him most, though, was the geography of the falls, the sheer drama of the place. Downstream at the Long Narrows, Parker highlighted what he believed would be the ultimate utility of the place - power. In the first reference to The Dalles as a generator of power, Parker wrote, "the falls and La Dalles furnish a situation for water-power equal to any in any part of the world." His notation in 1838 might appear surprising, considering that the fur trade still dominated Euro-American economic activity in the Columbia River Basin, but there were few places in North America in the early nineteenth century where rivers fell more than a few feet that someone did not see spinning waterwheels and prosperous factories. Nonetheless, Parker's take on the potential for the Columbia's most spectacular location of falling water remained largely ignored for over a half-century. ${ }^{5}$

By 1865, when Samuel Bowles published his best-selling travel account, Across the Continent, the river landscape in the Columbia River Gorge had 
changed markedly. Commercial transportation from coastal harbors to the interior, using the Columbia as a wealth-producing highway, dominated perspectives on the river by entrepreneurs in the burgeoning settler society on the lower river. In 1860, capitalists formed the Oregon Steam Navigation Company (OSN), a transportation combine that secured control of choke-points in the Gorge by building portage railways that linked three navigable sections on the river - Portland to Cascades, Cascades to The Dalles, and The Dalles to interior points - into an efficient commercial cartage system. OSN perfected its dominance of river transport only five years after government representatives had successfully pressured Indian tribes to cede millions of acres of land and to agree to leave the river. It was a breathtaking acquisition of place, a transformation of engagement with the river that represented perhaps the greatest revolution on the middle Columbia since the Pleistocene floods that had created the landscape of falling water. Samuel Bowles recognized that section of the river for what it had become. "The navigation of the Columbia River is now in the hands of a

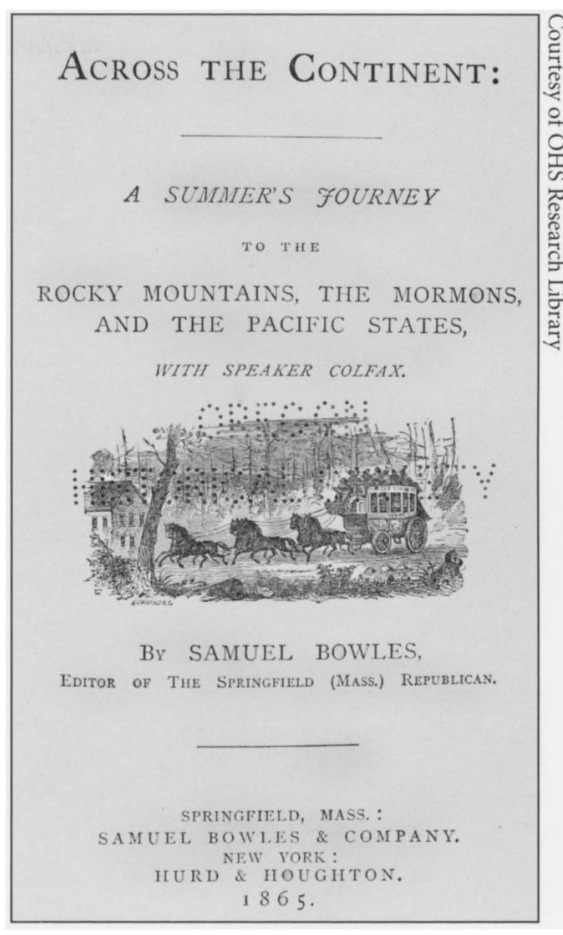

Samuel Bowles commented in his travelogue that the eastern half of the continent gave no indication of the landscape of the western half, which he described as a marvel. strong and energetic company," he wrote, "that not only have [sic] the capacity to improve all its present opportunities, but the foresight to seek out and create new ones. They are, indeed, making new paths in the wilderness, and show more comprehension of the situation and purpose to develop it than any set of men I have yet met on the Pacific Coast." Bowles described the vanguard of a new era on the river that in effect obviated the falling water, first in the cessation of Indian hegemony and second through the elimination of the rapids and falls as physical constraints on enterprise. Alexander Ross's "great emporium or mart of the Columbia" had been transformed into a new economic place. ${ }^{6}$

During the last decades of the nineteenth century, enterprise took hold of the river. Wealth from gold mining, stock raising, and cultivated wheat production in the Columbia Basin interior flowed down the Columbia to enrich communities near the lower river, especially Portland. Steamboats 


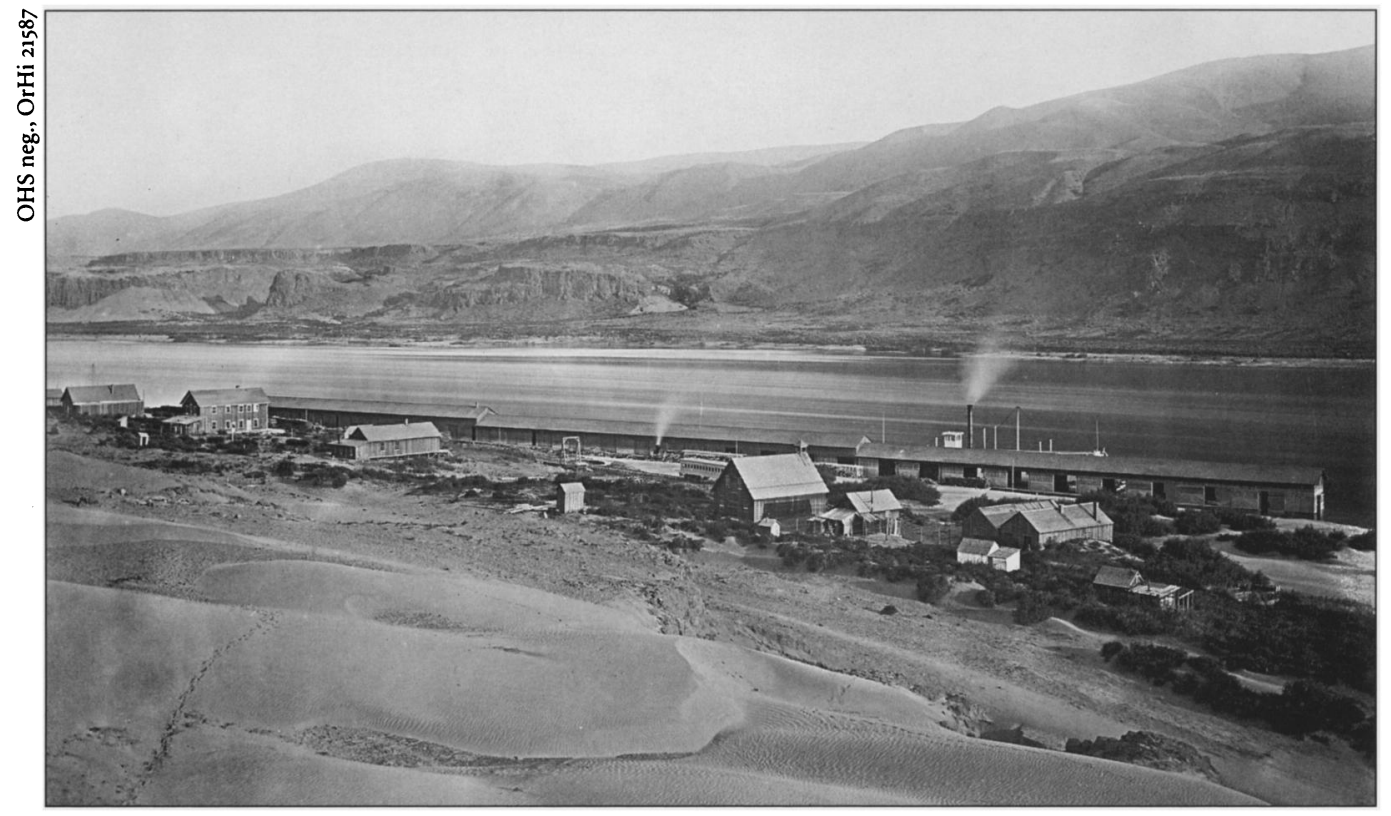

By 1867, when Carleton Watkins photographed this scene at the Celilo portage, the place had become an important staging area for the brisk upriver trade by steamboat.

provided new access for passengers, who made their way upriver in relative comfort as they appreciated the landscape from new perspectives. In July 1867 , a young Carleton Watkins rode upriver on an OSN boat to photograph the storied, dramatic scenery. His widely disseminated stereographs of OSN shipping operations, portage railroads, and the river at the Long Narrows and Celilo may have publicized the area more than any textual description. The public image of the Columbia and the rapids took on a new form, by artifice, and attracted a new appreciation. ${ }^{7}$ Watkins' photos, and the work of many other photographers, led to an aesthetic appreciation of the Columbia and its dramatic landscapes. By the 1880 os and 1890s, steamboat companies and the transcontinental railroad on the Oregon shore brought visitors to see the powerful river, the basalt cliffs, and the falling water. Railroad publicists promoted the middle-Columbia landscape as glorious, a place where "the scenery is arranged most effectively, becoming grander and wilder till the climax is reached at the marvelous rapids above Dalles City." It was a romantic viewpoint tailored for the visitor and pointedly bereft of earlier descriptions of the place. At the turn of the century, the complete rendition of Celilo Falls and The Dalles included romantic descriptions as well as references to ancient Indian fishing grounds, Lewis and Clark's difficult 
passage, and fur-trade-era conflicts over passage. In texts that portrayed an authoritative viewpoint on the history of the river - such as those written by Frances Fuller Victor, Joseph Gaston, William D. Lyman, and other popular writers - those disparate images of the middle Columbia found their way into a generalized picture of the place. ${ }^{9}$

In the early twentieth century, little foretold the future of Celilo Falls and The Dalles, but there were signs of a newer valuation of the place. "To provide for the rapidly incoming population," as Lyman wrote in 1909 in The Columbia River, the first comprehensive history of the river, "it was necessary that human labour and ingenuity modify the untamed forces of the river." ${ }^{10}$ That ingenuity had been applied at the Cascades, where by 1896 government engineers had created a by-pass canal that rendered the rapids irrelevant to river transportation. In 1905, engineers began working on a new, more difficult canalization at The Dalles and Celilo Falls. Finished in 1915, the canal became both a harbinger of more artificial constructions on the river and a testament to the logic of economic development. Enterprise increasingly vied with romance as a definer of the place. At the canal's dedication, J.N. Teal, an indefatigable promoter of river transportation improvements, told the gathered celebrants: "The river is free at last, and tolls based on the control of this portage will no longer be levied either by red man or white man. One chain was sundered at the Cascades; another we are breaking today; soon Priest Rapids will be freed, and then our dream will almost be realized." Readers who paid attention to Teal's Address, which was widely distributed and reprinted, understood that a new era had dawned, not because the canal would necessarily create the wealth Teal promised, but because it reified the vision of a completely reorganized river." "Above Celilo there are many rapids," Teal wrote,

which ultimately will be improved by means of locks and dams, and the general canalization of the river. With every dam, water power will be created, and this power should be utilized. ... All beneficial uses of these streams should be taken advantage of, and when they can be made available in connection with the improvement for navigation, it is worse than a blunder not to do so..$^{12}$

Waterpower, the focus of Samuel Parker's nearly forgotten comment many decades before, quickly became a preferred reason for development at The Dalles. The first official study of The Dalles as a hydroelectric location was published in 1900, when federal engineers first surveyed the site at Long Narrows for a power dam that would also improve navigation. ${ }^{13}$ Construction of The Dalles-Celilo Canal in 1915 answered the navigation question, while the power study rested on the shelf until 1905, when the state of Oregon took up the idea. Interest in damming big rivers to make 
electricity brought engineers to the Upper Missouri River in 1908, along the western slope of the Sierra Nevada in California by 1905, and to the Upper Colorado River in 1910. In the Pacific Northwest, engineers had succeeded in building a hydropower plant at Willamette Falls in 1889 and in sending its power to Portland, fourteen miles away, accomplishing the first long-distance transmission of direct current in the United States and the first transmission of alternating current the following year. ${ }^{14}$ Celilo Falls and The Dalles, rather than the object of concern as an obstacle to navigation, suddenly became a location for an economic bonanza, where engineers sought to exaggerate the river's fall and create a bountiful source of power.

In his report on building a dam at The Dalles, published in 1912, Oregon State Engineer John H. Lewis outlined what he believed to be "one of the largest and perhaps the cheapest water power project in the world." He proposed building a 180-foot high, 300-foot-long concrete river-blocking dam at Big Eddy, three miles upriver from The Dalles. The proposal included blasting an artificial channel some 300 feet wide and 20 feet deep through the basalt on the Washington side of the river, extending $1 \frac{1 / 2}{2}$ miles to a powerhouse, which would produce 300,000 horsepower from twenty-one turbines. Who might use so much power begged a question the engineer could not avoid. By 1912, Portland General Electric Company, the owner of six hydroelectric power stations and nine steam plants, dominated the electricity market in the Willamette Valley. ${ }^{15}$ How could the market absorb the additional power, approximately 10 percent of the power PGE supplied customers in 1910? The state engineer admitted at the outset that "the project looked ridiculous for want of a market," but his report promised that new "iron and steel reduction works, wood distillation, and the production of nitrogen fertilizer" would sprout by the dam once the power flowed. If that image of an industrialized landscape at The Dalles did not sufficiently answer the question, he expansively suggested, then the power plant could practically transform the region by electrifying the Columbia Basin, where the dreams of industrialists and agriculturalists could be realized. "Both Oregon and Washington are equally interested in this project," his report noted.

The United States is also interested because of its control over navigation, and because of the further fact that it is the owner of considerable vacant land along the Columbia River in both states which can be reclaimed only by pumping from the river. It is during the summer flood period that the greatest amount of power will be available. This is the season when such cheap power can be utilized for pumping purposes. ${ }^{16}$

The engineer's report was a harbinger of a dynamic, twentieth-century perspective on the falls and rapids. All dams swamp history, but the project planned for The Dalles portended a culturally significant alteration of a vis- 
ible landscape that had prevailed for thousands of years. Nineteenth-century travelers and early settlers had seen the place from many angles, but it had always retained its power and integrity, despite its problematic meaning for non-residents. Seeing the falls as a transformative place, where human artifice could alter geography and effect changes in distant locales, made Celilo and The Dalles a revolutionary place. The idea of a big dam proposed a radical rendering of place, while it masked or denied the falls' historic role as a conservative place, where continuity had reigned and community had aligned life with the falling water. A dam offered a revolutionary future. Spinning turbines would electrify distant machines and power siphons that would make the Columbia's water a commodity in a new era of expanded agriculture. The idea of the dam cast a broad shadow as reified opportunity, a grand opportunity, as J.N. Teal put it, "worse than a blunder" not to use.

The principal users of the Columbia when the idea of a big dam was first suggested were the fishers. For them, Celilo and the other fishing stations on the middle Columbia had become a treasure house. As early as the $188 \mathrm{os}$, commercial fishing interests had invaded the area to harvest tons of fish each year, claiming the landscape Indians had used for millennia. The companies that established operations in the middle Columbia brought new technologies with them, especially the monstrously efficient fishwheels. At the height of fishwheel use - from the 1880 s to the mid-1930s - more than thirty fixed fishwheels and fishwheel-scows operated at various times and places between Threemile Rapids and Celilo Falls. Fishwheels averaged fifty tons of fish each year, each one taking more than double what has been estimated as the annual catch of nonindustrial Indian fishers in the middle Columbia. ${ }^{17}$ Francis Seufert, owner of the largest cannery operation on the middle Columbia, bought fish from Indian fishers, but his business depended on the mechanical fishwheel harvests. After Oregon and Washington voters made fishwheels illegal (1926 and 1935), Seufert facilitated Indian fishing to make up for his lost catch, but that did not alter the plain reality of the new Celilo - the fishing places had changed hands from Native fishers to industrialists. The middle Columbia was an industrial fishing place, complete with machines; Chinese, Filipino, and other ethnic laborers; and a tinned product that went to the world with colorful labels proclaiming its origin. ${ }^{18}$

The investment by fishers at The Dalles and Celilo did not dampen the enthusiasm others had for altering the Columbia to suit their desires. Aspiring agricultural communities upriver from Celilo, for example, wanted a dam built at Umatilla Rapids to facilitate navigation and to impound a massive volume of river water for mid-Columbia irrigation projects. Earlier projects under auspices of the 1902 Reclamation Act had proved disappointing, but boomers believed that more water — much more water — would solve their 


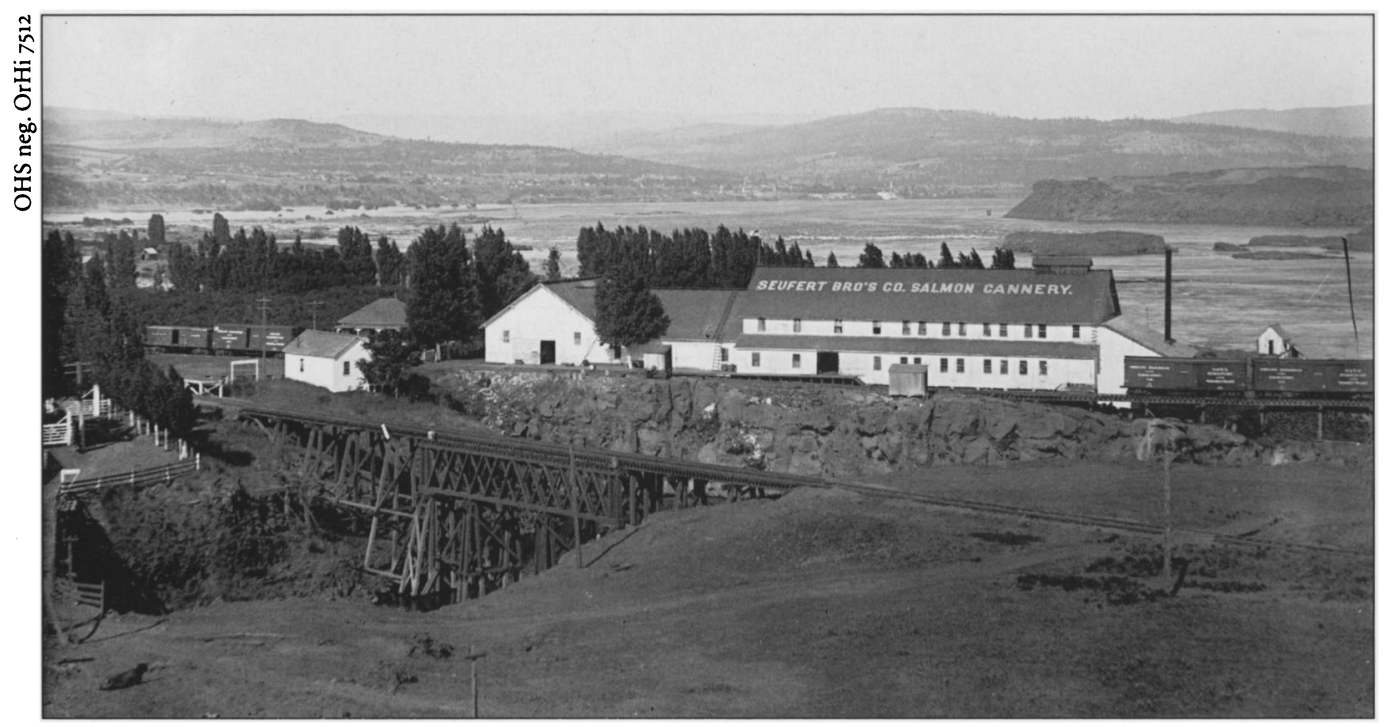

This photograph shows Seufert's cannery, perched on the edge of Fifteenmile Creek, with the location of Seufert's No. 1 and No.2 fishwheel sites and Threemile Rapids in the distance.

problems. Navigation interests, including shipping companies and port developers in Portland, talked up dams on the Columbia as a technological cornucopia that would make all communities wealthy. By 1922, a Bureau of Reclamation report concluded that a big dam at Umatilla Rapids was uneconomical, regardless of projected reclamation water use, but dam-promoters maintained a steady drumbeat of advocacy - they would finally succeed after World War II, when Congress authorized McNary Dam on the site.19

The dam site at The Dalles had not been the focus of irrigationists, but that changed when the power planners returned to the river. The so-called 308 Report on the Columbia, published in 1932, plotted ten main stem dams on the river, each at a promising power-generating and navigation-enhancing location. At The Dalles, federal engineers originally sketched out a massive high dam that would have backed up a reservoir for more than 100 miles up the mid-Columbia. The published report included a scaled-down version, with an additional dam at the John Day River and a smaller reservoir, but the consequence was the same - an end to Celilo Falls and fishing areas at Long Narrows and a new industrialization of the place, replacing the justoutlawed fishwheels with electrical dynamos and introducing another way to capture wealth from falling water. The place would be transformed. ${ }^{20}$

It is not an exaggeration to say that the 308 Report outlined the Columbia's future, but it may be more accurate to state that it established a frame- 
work for river developers and a target for those who wished to slow or halt the damming of the river. Celilo Falls became vulnerable to federal water resource planners, while individuals, fishing groups, and conservationists throughout the Pacific Northwest worried that the most ancient fishing ground in the region might disappear. Concerns about the fate of fish runs intensified after the U.S. Army Corps of Engineers completed Bonneville Dam in 1938 at river-mile 146, some seventy miles downriver from Celilo, because even optimistic estimates of fish passage made it clear that dams damaged fish runs. After World War II, planners went back to the 308 Report to make the Columbia River the world's greatest hydroelectric generating system, but Indian fishers and commercial fishing interests challenged the scheme, demanding that their interests, Celilo's ancient fishery, and the salmon be allowed to survive. Meetings held in the region from 1944 to 1948 gave the fishers no relief from the planned dam, even though the Corps' legal department warned that if the courts awarded Indians a property right in fish, the dams could be construed as violating their treaty fishing rights. The government planners willfully ignored the warning, although they included significant proposals to mitigate salmon losses caused by the dam. By 1948, the Corps of Engineers and the Bureau of Reclamation had completed major new studies of Columbia River water resources, and each identified The Dalles Dam as central to regional development, because it would add 701,00o kilowatts of prime power to the Pacific Northwest power grid and available power to run irrigation pumps in places as distant as Prineville and Bend, Oregon. ${ }^{21}$

In 1950, Congress authorized The Dalles Dam, and seven years later it stood ready to flood out ten millennia of human relationships at the most ancient place on the great river. An instrumental viewpoint had triumphed. The economic importance of fishing there and the cultural integrity of the place proved insufficient rationales for preservation. The falls had to become a new place. ${ }^{22}$ The gates closed in March 1957 and a stillness dropped on the falls, like an exhale of life. It was less than fifty years from the first detailed dam proposal to the day Celilo Falls disappeared. Inundating the falls caused enormous distress and pain for Indian people. That loss received some notice in newspapers, but a triumphalist perspective dominated media accounts of the dam. ${ }^{23}$ When noted regional author Stewart Holbrook published The Columbia in the "Rivers of America" series in 1956, he lamented the new river, declaring that he loved "the Columbia as it was more than as it is, or as it is likely to be next year," yet he did not hesitate to declare the river a new recreation place that would replace "the many homely and frail little civilizations that flourished at one time or another along its banks and on its waters." ${ }^{24}$ It might have appeared to be an improved river to some, but 


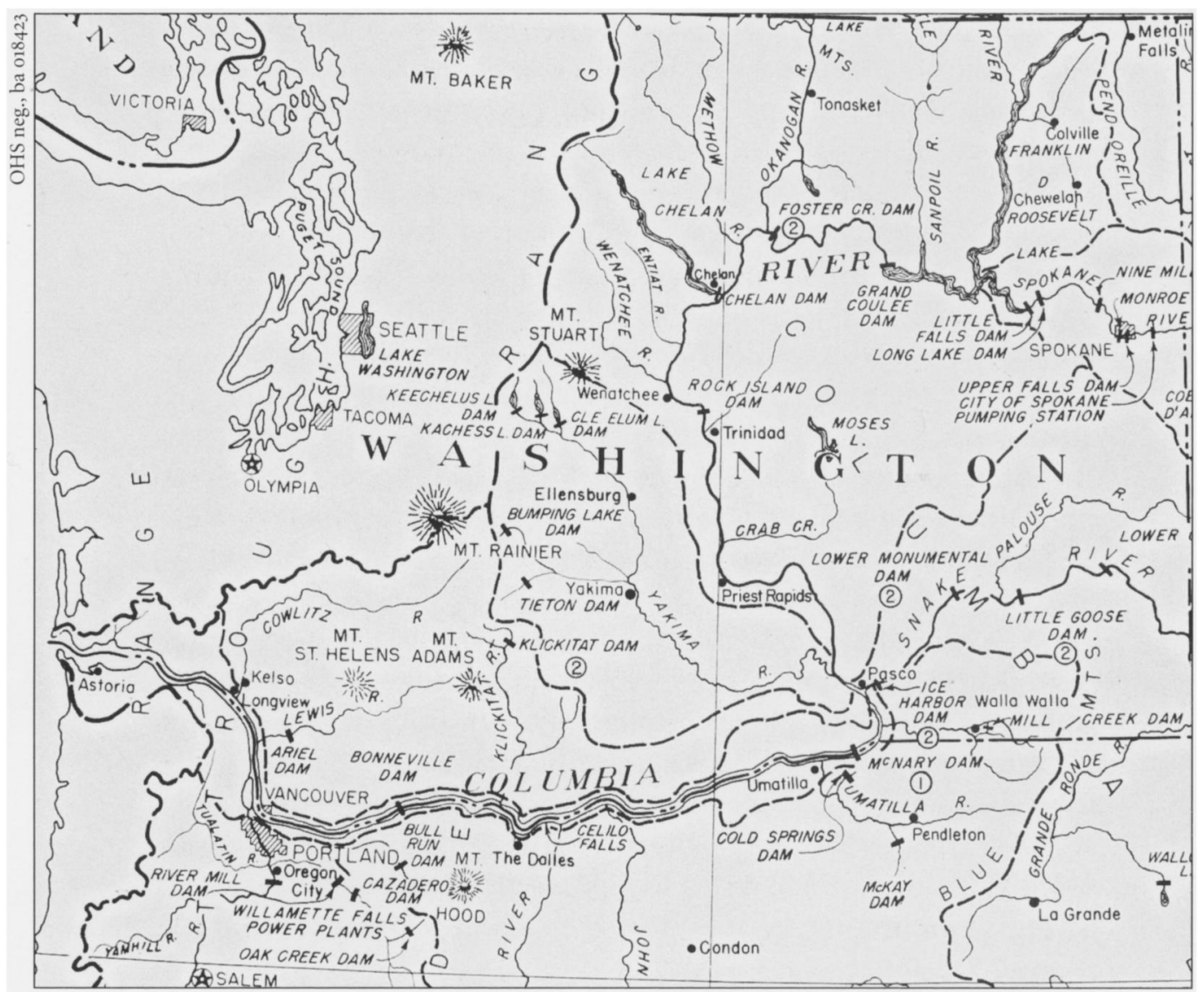

This map, part of the U.S. Army Corps of Engineer's revised 308 Report published in 1948, shows constructed and planned hydroelectric dams on the Columbia and Snake rivers.

the Columbia had lost a critical portion of its structure, and the great dam meant more distress to a distressed population of anadromous fish that had already declined in population during the preceding six decades. The fate of the fish and the people who lived by them became the next chapter in the history of falling water on the mid-Columbia.

One year after the inundation of Celilo Falls, the first of a series of popular books on the fate of salmon on the Columbia River appeared. Anthony Netboy, a conservation writer who had been hired by the Bonneville Power Administration to describe the condition of fisheries on the river, argued in Salmon of the Pacific Northwest: Fish vs. Dams that power production did not have to mean an end to fish runs. Netboy characterized the Celilo fishery as part of an old era. It was a place that progress justifiably changed, 
whose "origins are lost in the mists of unrecorded history." Indian fishers had to face a new era, Netboy explained, because "life is changing rapidly and the loss of the ancient grounds is but another step in the transition to a new and bewildering existence." This view of place pushed the social consequences of such great change to the margin, while underscoring the river's new technological status. The Dalles Dam, like others in the Columbia River system, would be a place of experimentation, where devices, studies, and clever mitigations would defuse the conflicts between fish and dams. "As we look ahead," Netboy wrote in 1958 , "it is inconceivable that the development of the Pacific Northwest's water resources will be indefinitely delayed by fish versus dam conflicts." 25

Netboy's optimistic interpretation of the radical transformation of the Columbia River's most storied fishing location can be seen as nearly equal parts hope and ambition, but his effective dismissal of Indian treaty rights missed the most important legacy of Celilo Falls. Indian fishers had gone to court in 1947 to halt the building of McNary Dam, and suits had been brought by Indians defending fishing rights at Celilo and Long Narrows locations during the 1940s; but the pendulum of change on the river did not really swing back for Indians until 1969, when Judge Robert Belloni ruled in Sohappy $v$. Smith that the state of Oregon had to honor Indians' treaty rights to fish in common with non-Indians. That ruling, combined with similar judgments by Judge George Boldt in Washington State, established a solid confirmation of Indian fishing rights on the Columbia in the areas that had supported fishing at the time of the treaties in 1855. As Fay Cohen explains in Treaties on Trial, even as a drowned-out place Celilo continued to exert influence. In federal courtrooms, state fisheries departments, and especially councils of tribal fishers, the falls remained the ultimate reference to loss of salmon, destruction of rights, and damage to people. The drowning of Celilo Falls had been traumatic, an event that defied adequate representation. The resuscitation of Indian fishing rights incrementally allowed Celilo a voice, a small but important representation in the remade world of the engineered Columbia. Cohen highlights the new significance of Celilo in recounting a 1981 three-hundred-mile walk Indians took from Celilo Falls to congressional hearings in Seattle as an effective protest against yet another diminution of their fishing rights. She quotes Indian poet Ed Edmo, who spoke from the hearings as if from the submerged Celilo: "The white man thinks the river is for sport, but it's not; the river is for life." ${ }^{26}$

The protest in 1981 defeated one of the many federal and state attempts to limit Indian fishing on the Columbia in the wake of the federal court decisions. During the 1980s and 1990s, anyone familiar with the fate of Indian fishers on the river understood that each defense of fishing rights was also a 
potential commentary on the fate of Celilo Falls. Journalists, historians, legal scholars, and advocates wrote about the effects of the decision to build The Dalles Dam. Few understood, though, how difficult defending fishing places and fishing rights had been until Roberta Ulrich, a journalist who had covered some of the disputes on the river as a correspondent for the Oregonian, wrote Empty Nets, which laid out a story of Indian resistance and persistence in seeking just compensation for their losses. Ulrich's narrative focuses on two competing views of Celilo and other Indian fishing places on the river; one saw those places as central to life and culture, the other saw them as at best nuisances and at worst impediments to the interests of society and even the survival of fish. Despite anyone's evaluation of the legitimacy of these views, a strikingly singular power resides in the attachment of history, life, and culture to Celilo Falls. Its power to symbolize its own struggle for life and the defense of like places is profound. Ulrich quotes Yakama historian Richard LaCourse: "The loss of the historic falls was the darkest day in the common psychological history of the tribe in the current century. The policy of termination was incarnated in the destruction." ${ }^{27}$

The story of destruction at Celilo drew interest from historians. Most of them told the story of development, but a few began to look at Celilo and The Dalles as places. Charles Wilkinson's analyses of fishing rights cases and their importance in changing the face of the American West, as in his Crossing the Next Meridian, gives Celilo Falls an important part in the drama. The most thorough historical account, though, is Katrine Barber's Death of Celilo Falls, an ambitious book that makes clear why the end of a place does not mean the end of its influence. Celilo's depth in cultural importance, economic value, and spiritual significance could not be purchased, yet that was exactly what the federal government proposed to do by offering a singular compensation to Indian fishers for transforming Celilo from a productive place to a painful memory. Even if that compensation had been just, which Barber makes clear it was not, there is no calculus for such an exchange - a living place for abstract economic benefits. The place for living, Celilo Village near the drowned falls, became a place of ongoing tension between federal authorities and the remaining community. The power of the falls devolved to a small and embattled place, where poverty rarely lifted and most outside the community wanted it to fade from view. Barber quotes village resident Arita Davis on why the place remains important: "I hope you can understand. We don't 'come from' anywhere; this is where we were born, this is where we lived all our lives and we don't want to leave." ${ }^{28}$

The power of place is centered in human experience. Understanding that experience at Celilo Falls and The Dalles requires the horizontal viewpoint that geographer Yi-Fu Tuan identifies as complex and the near opposite of 
an aesthetic perspective. It is one, Tuan argues, that can be expressed "only with difficulty and indirectly through behavior, local tradition, lore, and myth." ${ }^{29}$ By the end of the twentieth century, people who knew Celilo from experience began publishing their memories of a place connected to them through tradition, lore, and myth. Working with anthropologist Eugene Hunn, James Selam described his family's fishing community at Sk'in just below Celilo Falls on the Washington side of the Columbia, where fishers seined their fish from a sand spit. Selam remembered it as a place governed by a complex set of relationships, but also a landscape of stories, where specific locations held stories that explained how Coyote brought salmon to the people or why salmon returned each year. He described the place from inside, looking out at the world from the fishing place, not from outside looking in. ${ }^{30}$ Allen Pinkham, in Salmon and His People, collected descriptions from Nez Perce fishers who remembered Celilo as "one continuous, deafening roar [with] a sound and smell all its own." In their memories, Celilo emerges as a place of profound connection, from father to son, uncle to nephew and niece, and today to a millennial past. "It gave me a feeling and assured me," Levi Holt remembered of his fishing with relatives, "that all Indian people honored the salmon in the same way." ${ }^{11}$ In memory, Celilo remains a living force, because Indian people reject the idea that it is irrelevant to their lives today.

Memories of place require detail, context, and social connection to communicate meaning. The idea of a memorialized place in the western tradition often requires a separation or distance from the present, where the details and context of living are walled off and assigned a static existence in the past. In When the River Ran Wild!, Kiksht Chinookan fisherman George Aguilar's dynamic description of the culture ways of mid-Columbia Indians, the memorial to Celilo is embedded in details that link fishing gear to family work to proper behavior to jokes told about conflicts over good fishing spots. The fishing landscape at Celilo, Aguilar explains, was more than good gaffing points or spots where fish were available nearly year round. It was a living landscape, where humans and fish shared the environment, where every human action rippled through nature. Ending fishing at Celilo and drowning the place, Aguilar suggests, does not erase the memory and its ability to instruct the living. ${ }^{32}$ Instruction, however, does not reside in the memorialized place. It is pried loose by questions, especially those posed by people whose lives are shaped by the consequences of profound change. In As Days Go By, a history of the Cayuse, Umatilla, and Walla Walla of the Confederated Tribes of the Umatilla Indian Reservation, and The Si'lailo Way, an investigation of Indians and law on the Columbia River written by Indian lawyers, significant events in Celilo's legal history extend the reach 


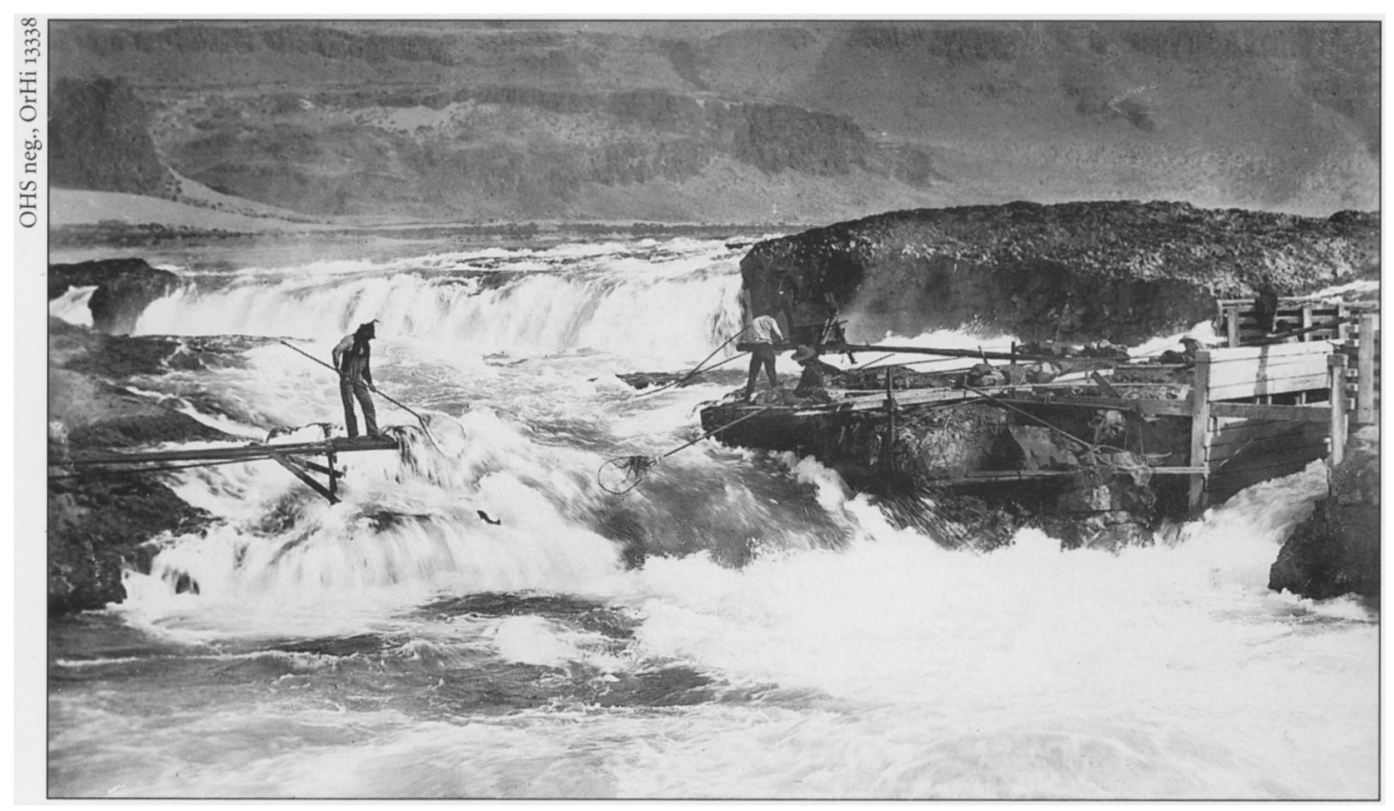

This photograph, taken by Benjamin A. Gifford in 1899 and published in When the River Ran Wild! by George W. Aguilar, Sr., shows Indians fishing just downstream from Horseshoe Falls at Downes Channel. In 1936, Francis Seufert installed a cableway from the shoreline, on the right, to Chiefs Island, on the left, to increase the efficiency of the Native fishery at Celilo.

of fishing rights, the importance of tribal sovereignty, and the reshaping of property relationships between Indian people and the Columbia River. The meaning, as Umatilla tribal judge William Thompson writes, is that Indian fishers at Celilo "were free and independent, and we exercised our sovereignty the same way. We could provide for ourselves. We have regained that now with a different economy, which still includes the Way'am values." ${ }_{33}$

Celilo Falls and The Dalles emerge from the literature as complex places that cannot be understood from one vantage point. The visitor's perspective is as necessary as the resident's. Neither can carry the burden of explaining the place, what has happened there, and what social and cultural meaning should stand as description. In the massive changes brought through the application of brute-force technologies in the twentieth century, there was such a transformation to the landscape that trauma became a powerful addition to the previous list of human reactions to Celilo, the place, and its history. No place is fixed and all places change with time, but inherent to the path of change is its meaning, the web of connections that keeps us attached to it. 


\section{NOTES}

1. E.V. Walter, Placeways: A Theory of the Human Environment (Chapel Hill: University of North Carolina Press, 1988), 3-22.

2. Yi-Fu Tuan, Topophilia, A Study of Environmental Perception, Attitudes, and Values (Englewood Cliffs, N.J.: Prentice-Hall, 1974), 64; The Journal of Patrick Gass, The Journals of the Lewis \& Clark Expedition, ed. Gary Moulton, vol. 10, (Lincoln: University of Nebraska Press, 1996), 160-61. For discussion of the publication of Gass's journal, see Donald Jackson, “The Race to Publish Lewis and Clark," in James P. Ronda, ed., Voyages of Discovery: Essays on the Lewis and Clark Expedition (Helena: Montana Historical Society Press, 1998), 209-28.

3. [Nicholas Biddle], History of the Expedition under the Command of Captains Lewis and Clark, to the Sources of the Missouri, Across the Rocky Mountains and down the River Columbia to the Pacific Ocean (Philadelphia: Bradford and Inskeep, 1814), 2:32-34.

4. Washington Irving, Astoria or Anecdotes of an Enterprise Beyond the Rocky Mountains, Keystone Western Americana Series (Philadelphia: J.B. Lippincott Company, 1961) 2:281-83; John Kirk Townsend, Narrative of a Journey Across the Rocky Mountains, to the Columbia River... Northwest Reprints (Corvallis: Oregon State University Press, 1999), 115; Alexander Ross, Adventures of the first Settlers on the Oregon or Columbia River, 1810-1813, Bison Books (Lincoln: University of Nebraska Press, 1986), 132, 128-30. In his preface to this edition of Ross's memoir, historian James P. Ronda emphasizes that this is an important eyewitness account of life on the Columbia and that Ross used his own journals, not his memory, for details of his travel up the Columbia.

5. Samuel Parker, Journal of an Exploring tour Beyond the Rocky Mountains under the direction of the A.B.C.F.M. performed in the years 1835 , ' 36 , and ' 37 (Ithaca, N.Y., by the author, 1838), 130. Government-sponsored surveys of the West that included descriptions of the Columbia River Gorge appeared during the 1840 and 1850 , written by scientists, government explorers, and military surveyors. Prominent examples are: Solomon Nunes Carvalho, Incidents of travel and adventure in the far West : with Col. Frémont's last expedition across the Rocky Mountains : including three months' residence in Utah and a perilous trip across the great American desert to the Pacific (New York: Derby \& Jackson, 1857); Charles Wilkes, Narrative of the United States Exploring Expedition, during the Years 1838, 1839, 1840, 1841, 1842 (Philadelphia: C. Sherman, 1844); James D. Dana, United States Exploring Expedition, during the Years 1838, $1839,1840,1841,1842$, Under the Command of Charles Wilkes, U.S.N., Geology (New York: Putnam, 1849); Horatio Hale, "Ethnology and Philology," in Narrative of the United States Exploring Expedition during the years 1838-1842 (Philadelphia: Lea and Blanchard, 1846); and Henry L. Abbot, Explorations for a Railroad Route, from the Sacramento Valley to the Columbia River made by Lieut. R.S. Williamson, Corps of Topographical Engineers, vol. 6, pt. 1 of Reports of Explorations and Surveys, to Ascertain the Most Practicable and Economical Route for a Railroad from the Mississippi River to the Pacific Ocean (Washington, D.C.: A.O.P. Nicholson, 1857). For a survey of scientific discovery about the landscape, see Jim E. O'Connor, “The Evolving Landscape of the Columbia River Gorge: Lewis and Clark and Cataclysms on the Columbia," Oregon Historical Quarterly 105:3 (Fall 2004): 390-421. For scholarly appraisal of missionary viewpoints on Indians at Celilo Falls and The Dalles, see Robert Boyd, People of the Dalles: The Indians of Wascopam Mission (Lincoln: University of Nebraska Press, 1996).

6. Samuel Bowles, Across the Continent: A Summer's Journey to the Rocky Mountains, the Mormons, and the Pacific States, with Speaker Colfax (Springfield, Mass: Samuel Bowles and Company; NY: Hurd \& Houghton, 1865), 192-93.

7. For descriptions and analysis of 
Carleton Watkins and his Columbia River photographs, see Peter Palmquist, Carleton E. Watkins, photographer of the American West (Albuquerque: Published for the Amon Carter Museum by the University of New Mexico Press, 1983); and James Alinder, ed., Carleton E. Watkins: Photographs of the Columbia River and Oregon (Carmel, Calif: Friends of Photography, 1979).

8. Henry T. Finck, The Pacific Coast Scenic Tour (New York: Charles Scribner's Sons, 1890), 189. For similar descriptions, see Union Pacific Railroad, Wealth and Resources of Oregon and Washington (Portland, Ore.: Passenger Department, Union Pacific Railway, 1889).

9. For examples, see Francis Fuller Victor, Atlantis Arisen (Philadelphia: J.B. Lippincott, 1891), 54; H.H. Bancroft, The works of Hubert Howe Bancroft (San Francisco: A.L. Bancroft, 1883-1890) 29:406-410; Joseph Gaston, The Centennial History of Oregon (Chicago: S.T. Clarke, 1912), 123; and William D. Lyman, The Columbia River: Its History, Its Myths, Its Scenery, Its Commerce (NY: G.P. Putnam's Sons, 1909).

10. Lyman, The Columbia River, 3rd ed., 270.

11. Lewis R. Freeman commented on the failure of the canal to live up to its promise: "There is not a steamer running regularly on the Columbia above The Dalles to-day." Freeman, Down the Columbia (N.Y.: Dodd, Mead and Co., 1921), 357.

12. Joseph Nathan Teal, Address of Joseph N. Teal, Chairman of the Day, The DallesCelilo Canal Celebration, Big Eddy, Oregon, May 5, 1915.

13. For the federal study by U.S. Army Corps of Engineers, see House Document 228, 56th Congress, 2nd Sess, November 30, 1900. William Harts, District Engineer and author of the study, planned to channel water from the head of Fivemile Rapids to the foot of Celilo Falls, but the idea became moot when construction on The Dalles-Celilo Canal began.

14. Craig Wollner, Electrifying Eden: Port- land General Electric, 1889-1965 (Portland: Oregon Historical Society Press, 1990), 24-28.

15. Ibid., 63-64.

16. John H. Lewis, The Columbia River power project near The Dalles, Oregon, with detailed technical report by L.F. Harza and V.H. Reineking (Salem: State of Oregon, 1912). The report was issued as a supplement to the fourth biennial report of the state engineer. The state engineer had assistance from U.S. Engineer Department, USGS, and the engineering departments of the OWR\&N and North Bank railroads.

17. For discussion of fish comparative capture by Indians and fishwheels, see Randall F. Schalk, "Estimating Salmon and Steelhead Usage in the Columbia Basin Before 1850: An Anthropological Perspective," The Northwest Environmental Journal 2 (Summer 1986): 14-21; Ivan J. Donaldson and Frederick K. Cramer, Fishwheels of the Columbia (Portland, Ore.: Binfords \& Mort, 1971), 83-113; and Joseph E. Taylor, III, Making Salmon: An Environmental History of the Northwest Fisheries Crisis (Seattle: University of Washington Press, 1999), 22-23, 63-65.

18. W.A. Jones, The Salmon Fisheries of the Columbia River, Sen. Exec. Doc 123, 5oth Cong., 1st sess. (1887); and Francis Seufert, Wheels of Fortune (Portland: Oregon Historical Society, 1980), 40-50.

19. E.A. Crocker Report, Committee on Irrigation and Reclamation, 68th Cong., 1st sess., 1924, 5-7. On early efforts to irrigate the region between Celilo and the Snake River, see Keith C. Petersen, River of Life, Channel of Death: Fish and Dams on the Lower Snake (Lewiston, Idaho: Confluence Press, 1995), 104-105.

20. U.S. Congress, House Doc. No. 103, Columbia River and Minor Tributaries, 73rd Cong., 1st sess. (1932). For the best recent discussion of this important government publication, see William F. Willingham, Northwest Passages: A History of the Seattle District, U.S. Army Corps of Engineers Volume II, 1920-1970 (Seattle: U.S. Army Corps of Engineers, 2006), 2-17. 
21. U.S. Department of the Interior, Bureau of Reclamation, The Columbia River (Washington, D.C., February 1947)2: 272-73; U.S. Army Corps of Engineers, North Pacific Division, Review Report on Columbia River and Tributaries, Appendix L: Main Columbia River Below Yakima River (Portland, Ore.: October 1, 1948), L-133. A follow-up “308” report prepared in 1937 (House Doc. No. 704, 75th Cong., 3rd sess.) set the length of the proposed reservoir to extend to the John Day River, and an "Interim" report on March 21, 1946, extended the reservoir to increase the power generation capacity, L119-120. For the legal cautionary, see Corps of Engineers, Review Report, Appendix Q: Legal, Q-47-54.

22. The first published history to include reference to The Dalles Dam noted that only the U.S. Fish and Wildlife Service had strenuously complained about the dam's effects and argued to prevent its building, but the outcome was only to generate mitigation proposals. See Charles McKinley, Uncle Sam in the Pacific Northwest: Federal Management of Natural Resources in the Columbia River Valley (Berkeley: University of California Press, 1952), 387-88, 429-30.

23. For discussion of the press accounts of building The Dalles Dam and aftermath, see Jon S. Arakaki, "From Abstract to Concrete: Press Promotion, Progress, and the Dams of the Mid-Columbia (1928-1958)," (Ph.D. diss., University of Oregon, 2006), 165-92.

24. Stewart Holbrook, The Columbia, Rivers of America, ed. Carl Cramer (New York: Rinehart and Co., Inc: 1956), 330.

25. Anthony Netboy, Salmon of the Pacific Northwest: Fish vs. Dams (Portland, Ore.: Binfords \& Mort, 1958), 17-18, 116. Netboy followed up this study twenty-two years later with The Columbia River Salmon and Steelhead Trout: Their Fight for Survival (Seattle: University of Washington Press, 1980). In that book, he further criticized Indian fishers who had lost the Celilo fishery, essentially for pursuing their treaty rights. Netboy concluded that the 1969 decision in Sohappy v. Smith that honored the treaty had "opened a can of worms which has since plagued efforts at administering the fishery in a manner that is 'fair and equitable' to all user groups, and most of all it has inhibited efforts to save a declining resource" (126).

26. Fay G. Cohen, Treaties on Trial: The Continuing Controversy over Northwest Indian Fishing Rights (Seattle: University of Washington Press, 1986), 121-23, 134-35, 175-76.

27. Roberta Ulrich, Empty Nets: Indians, Dams, and the Columbia River (Corvallis: Oregon State University Press, 1999), 80.

28. Charles Wilkinson, American Indians, Time, and the Law (New Haven: Yale University Press, 1987), Crossing the Next Meridian: Land, Water, and the Future of the West (Washington, D.C.: Island Press, 1992), and Messages from Frank's Landing: A Story of Salmon, Treaties, and the Indian Way (Seattle: University of Washington Press, 2000); and Katrine Barber, Death of Celilo Falls (Seattle: University of Washington Press, 2005), 154.

29. Tuan, Topophilia, 63.

30. Eugene S. Hunn, with James Selam and Family, Nch'i-Wána, "The Big River": Mid-Columbia Indians and Their Land (Seattle: University of Washington Press, 1990), 153-56.

31. Dan Landeen and Allen Pinkham, Salmon and His People: Fish and Fishing in Nez Perce Culture (Lewiston, Idaho: Confluence Press, 1999), 77-83.

32. George W. Aguilar, Sr., When the River Ran Wild!: Indian Tradition on the Mid-Columbia and the Warm Springs Reservation (Portland: Oregon Historical Society Press, 2005), 112-25.

33. Jennifer Karson, ed., As Days Go By: Our History, Our Land, and Our People, the Cayuse, Umatilla, and Walla Walla (Portland: Oregon Historical Society Press, 2006), 15788 , quote at page 180 ; and Joseph C. Dupris, Kathleen S. Hill, and William Rodgers, Jr., The Si'lailo Way: Indians, Salmon and Law on the Columbia River (Durham, N.C.: Carolina Academic Press, 2006), 339-60. 